Acta Veterinaria (Beograd), Vol. 63, No. 5-6, 621-629, 2013.

DOI: 10.2298/AVB1306621S

UDK: $332.63+636.37: 574.1+575.17$

\title{
DETERMINING THE VALUE OF VLASHKO-VITOROGA ZACKEL SHEEP FOR THE CONSERVATION PROCESS
}

\author{
SAVIĆ MILA, TRAILOVIĆ RUŽICA, PETRUJKIĆ B, BEČKEI Ž, DIMITRIJEVIĆ B \\ and DIMITRIJEVIĆ V
}

University of Belgrade, Faculty of Veterinary Medicine, Serbia

(Received $1^{\text {th }}$ June 2013)

\begin{abstract}
Autochthonous Pramenka (Zackel) sheep has been recognized as an important element of regional agro-biodiversity, relevant to the tradition that encompasses the cultural heritage of Serbia. The recognition that locally adapted animal breeds gained genetic resistance and adaptability through evolution; modern sustainable farming practices are far more attuned to the need for preserving and utilizing Zackel sheep types. The risk factors leading to rapid and severe decline in Vlashko-Vitoroga Zackel sheep population have been described in the paper. The objective of the study was to obtain the data necessary for development of conservation and sustainable use strategies of Vlashko-Vitoroga Zackel sheep. Determination of the conservation value upon characteristics of the breed was performed, in aim to identify priorities in accordance with the criteria of Food and Agriculture Organization of the United Nations (FAO). The positive and negative characteristics of the Vlashko-Vitoroga Zackel sheep, opportunities for utilization, as well as ambiental challenges that affect the breed were analyzed in the paper. The importance of this breed for maintenance of cultural tradition, landscape preservation and longterm rural development by in-situ conservation through utilization is also discussed in the paper.
\end{abstract}

Key words: biodiversity, conservation, Vlashko-Vitoroga Zackel sheep, Zackel sheep

\section{INTRODUCTION}

The conservation of animal genetic resources is a debating area in animal breeding science due to the complexity of the criteria used to define the breed/s suitable for the process and due to the economic support necessary for success of the strategy involving national and global development planning. 
The information on evolutive development involved in adaptation on local and/or regional ambient, which leads to diversification of different breeds/types within species, together with the data on genetic relationships among local breeds can be crucial for choosing the population for conservation planning (Lenstra et al., 2012). The socio-economic importance of the breed/type, both contemporary and future, also influences decision at a national level. Also, important factors are the demographic status determined upon effective breeding population size, and length of the reproductive cycle. In addition, the following criteria defined by FAO (FAO, 2009, 2012b) should also be considered: breed specific phenotypic variable and productive traits, adaptability to specific environment, genetic variability, and importance for comparative studies. The attractivity of the breed used for determination of the esthetic value and promotion of breeding region, as well as local cultural and historic importance are important decision-making factors, too (FAO, 2010, 2012c).

The Zackel sheep breed is the most important native group of sheep breeds in Serbia. The breed group developed under varying biogeographic conditions in Central and Southeastern Europe, and inhabited various regions during the history of European sheep breeding. Some populations, due to characteristic climate conditions and phytocenosis, exhibit a greater degree of adaptation to ambiental conditions in the local habitat. The unique characteristic of different types of Zackel sheep is an exceptional adaptation to harsh environmental conditions. Specific environmental conditions, such as climate, hydrological parameters, grazing quality and others, along with historical migrations of animals induced individualized microevolutive adaptations of Zackel sheep types to their respective habitats. In Serbia this process resulted in the separation of 11 different types (Stojanović, 2009). The majority of autochthonous sheep types became endangered by the end of the 20th century in Serbia and once large local populations of different Zackel sheep are currently undergoing negative demographic trends. Several reasons for the loss of animal genetic diversity in Serbia have been identified. A major route for endangering autochthonous sheep breeds has been uncontrolled cross-breeding and crossing with exotics breeds (Wurttemberg, Ile de France, etc.), in order to improve wool production and fattening ability. Consequently, certain Zackel types, such as Lipe sheep and Vlashko-Vitoroga sheep, are already endangered and the number of breeding animals is declining.

Various investigations have been performed in order to evaluate the genetic characteristics, status and characteristics of local Zackel sheep types. (Trailović et al., 2006; Ćinkulov et al., 2008; Savić et al., 2011; Savić, 2012).

The objective of the present study was to evaluate the status of VlashkoVitoroga Zackel sheep and to identify conservation strategies by analyzing the characteristics of the breed along with the prospects and future challenges. Inputs were related to the description of the characteristics of the breed, its history, its functions and characteristics of the habitat and production system where it is used. 


\section{MATERIALS AND METHODS}

The survey was conducted over a two-month period, April through May in 2011, in South Banat region in order to document the characteristics and existing production system, population status and breed characteristics of VlashkoVitoroga Zackel sheep. In total, 50 adult females and 8 adult males from two populations of pure breed Vlashko-Vitoroga Zackel sheep traditionally reared in Bela crkva and Kovin municipalities have been examined. Measurements were taken early in the morning when the animals were still in the barns. Wool samples were taken during shearing. Qualitative and quantitative variable traits were estimated in accordance with FAO Guidelines for phenotypic characterization of Animal Genetic Resources (AnGR) (FAO, 2012a). Fiber diameter was determined with an optical fiber diameter fineness analyzer (OFDA-GSG, Australia Ltd.), as described by Baxter et al. (1992). The data processing was performed by using the statistical software GraphPad Prism 5.0 (GraphPad Software, Inc., USA).

The present status of Vlashko-Vitoroga Zackel sheep within its production system and the strategies for the future management were analyzed according to FAO guidelines (Gandini and Oldenbroek, 2007; Martin-Collado et al., 2012; FAO, 2013).

\section{RESULTS}

\section{Population status}

According to the breed classification system provided by FAO (FAO Domestic Animal Diversity Information Service (FAO DAD IS), Vlashko-Vitoroga Zackel sheep, which is the official name, is a transboundary breed. Taxonomic problems related to Valachian (Zackel) heritage phyletic sheep group have already been recognized (Drăgănescu and Grosu, 2010). Vlashko-Vitoroga Zackel sheep has inhabited Serbia for a sufficient period of time to be genetically adapted to traditional production systems and environments in the region, especially in South-East Banat. According to the literature (Nikolić, 1951), Vlashko-Vitoroga Zackel sheep (Stogoš, Rackulja, Stepska ovca, Vlaška vitoroga) was described as "the breed that is almost exclusively grown in the Southeastern Banat, mostly in the area of quicksand and also as: "a very primitive and extremely resistant sheep". Simultaneously with the development of intensive livestock production systems, the decline of Vlashko-Vitoroga Zackel sheep occurred. Crossbreeding and subsequent replacement of locally adapted Vlashko-Vitoroga Zackel sheep by exotic breeds are identified as the main reasons for the loss of genetic diversity. Literature data (Mitić, 1984) showed that only a small number of individuals remained, hence underlying the historical significance of Vlashko-Vitoroga Zackel sheep. The size of the population continued to drop to its lowest point at the beginning of the last decade. Fortunately, conservation programs were initiated, 
and the current number of pure-bred sheep is around 500 and is slowly increasing (FAO DAD IS, 2012). However, Vlashko-Vitoroga Zackel sheep remains recognized as an endangered breed, and is registered at the Endangered Maintained breeds list (FAO DAD IS, 2012).

\section{Adaptation to habitat and production system}

Animals occupy the habitats in the South Banat region: Bela Crkva and Kovin municipalities at the edge of Deliblatska Peščara. The Deliblatska Peščara, originates from a prehistoric desert and covers area of over $300 \mathrm{~km}^{2}$ between the Danube River and Carpathian Mountains. Thus, the natural habitat of VlashkoVitoroga Zackel sheep is located at $44^{\circ} 45^{\prime}-4507^{\prime} \mathrm{N}$ latitude and $20^{\circ} 58^{\prime}-21^{\circ} 25^{\prime}$ $\mathrm{E}$ longitude, and $80 \mathrm{~m}$ altitude. Generally, the region has a temperate continental climate with temperatures varying from $-5 \mathrm{C}$ to $+10 \mathrm{C}$ in winter, and from $+23 \mathrm{C}$ to $+35 \mathrm{C}$ in the summer. Winters and summers are short, but extreme with temperatures of $-20 \mathrm{C}$ and over $+40 \mathrm{C}$, respectively. Southern Banat is the windiest region in the Pannonian Plain with strongest Košava wind. The maximal wind speed recorded is over $75 \mathrm{~km} / \mathrm{h}$.

The adaptive traits of Vlashko-Vitoroga Zackel sheep should be specifically reviewed in the context of the resistance of the breed to special conditions on the Deliblatska Peščara. This region can be considered as a potential High Nature Value (HNV) farming system. The climate in Deliblatska Peščara area is semi-arid. Pedology describes several types and sub-types of soil in Deliblatska Peščara: the dunes are layers of black and grayish-yellow sand, while the transition zone from sand to loess and sandy chernozem to pure chernozem surrounds Deliblatska Peščara. Analysis of the botanical composition revealed plant diversity and nutritious value of sheep pastures in the periphery of the Deliblatska peščara (Grdović et al., 2012). Vlashko-Vitoroga Zackel sheep is a frugal and sturdy animal, well-adapted to low input, rigorous and often nomadic lifestyle.

\section{Breed description}

The characteristic phenotypic traits of Vlashko-Vitoroga Zackel sheep are presented in Table 1. The Vlashko-Vitoroga Zackel sheep is an unspecialized, triple-purpose breed with outstanding vertical and spirally twisted horns corkscrew shaped on both sexes. Head and legs are covered with yellow to chestnut hair, while the body wool can be white, yellow, chestnut or black (Table 1). The local type of Vlashko-Vitoroga Zackel sheep (Žuja-yellow) is unique for yellow-brownish color of hair and fleece. Fleece is open with long whippy locks and long rough fibers $(25-30 \mathrm{~cm})$ with the diameter ranging from $38.20 \pm 1.69 \mu \mathrm{m}$ to $41.13 \pm 2.23 \mu \mathrm{m}$. Average adult ewes weight $41.85 \pm 3.06 \mathrm{~kg}$ and are $62.90 \pm 2.41 \mathrm{~cm}$ high at withers, while rams weight $54.31 \pm 2.74 \mathrm{~kg}$ and are $70.63 \pm 3.02 \mathrm{~cm}$ high (Table 1). Annual milk production of Vlashko-Vitoroga Zackel sheep is $80-110 \mathrm{~kg}$ per lactation period. It is a late-maturing breed with average fertility rate of $120 \%$.(Table 1 ). 
Table1. Breed description of Vlashko-Vitoroga Zackel sheep

\begin{tabular}{|c|c|c|}
\hline Parameter & \multicolumn{2}{|c|}{ Description } \\
\hline $\begin{array}{l}\text { Origin and development: } \\
\text {-description of origin } \\
\text {-location within country }\end{array}$ & \multicolumn{2}{|c|}{$\begin{array}{l}\text { Vlashko-Vitoroga Zackel sheep has inhabited Serbia for } \\
\text { sufficient time to be genetically adapted to traditional } \\
\text { production systems and environments in the region } \\
\text { especially in South-East Banat. }\end{array}$} \\
\hline Uses & \multicolumn{2}{|c|}{$\begin{array}{l}\text { The Vlashko-Vitoroga Zackel is unspecialized, triple- } \\
\text { purpose sheep breed (milk, lamb meat and wool) }\end{array}$} \\
\hline Breed qualities information & \multicolumn{2}{|c|}{$\begin{array}{l}\text { Adaptability to specific environment: the breed is known } \\
\text { for its adaptability to extreme climatic conditions. }\end{array}$} \\
\hline Breed colours & \multicolumn{2}{|c|}{$\begin{array}{l}\text { Head and legs are covered with yellow to chestnut hair, } \\
\text { while the body wool can be white, yellow, chestnut or } \\
\text { black. The local type of Vlashko-Vitoroga Zackel sheep } \\
\text { (Žuja-yellow) is unique for its yellow-brownish color of } \\
\text { hair and fleece. }\end{array}$} \\
\hline Other specific visible traits & \multicolumn{2}{|c|}{$\begin{array}{l}\text { Horns are spirally twisted, vertical corkscrew shaped on } \\
\text { both sexes. }\end{array}$} \\
\hline & rams & ewes \\
\hline Wither height (avg.) & $61.24 \pm 2.13 \mathrm{~cm}$ & $54.24 \pm 2.04 \mathrm{~cm}$ \\
\hline Weight (avg.) & $40 \pm 5 \mathrm{~kg}$ & $35 \pm 5 \mathrm{~kg}$ \\
\hline $\begin{array}{l}\text { Fleece: open, long whippy } \\
\text { locks and long rough fibers }\end{array}$ & $29.57 \pm 2.32 \mathrm{~cm}$ & $25.52 \pm 2.10 \mathrm{~cm}$ \\
\hline Wool (fibre diameter) & $41.15 \pm 3.51 \mu \mathrm{m}$ & $38.22 \pm 2.61 \mu \mathrm{m}$ \\
\hline Age of sexual maturity (avg.) & \multicolumn{2}{|c|}{18 months } \\
\hline $\begin{array}{l}\text { Age of full growth } \\
\text { (late maturing breed) }\end{array}$ & \multicolumn{2}{|c|}{ 3-4 years } \\
\hline Lactation lenght & \multicolumn{2}{|c|}{$100-150$ days } \\
\hline Milk yeild per lactation & \multicolumn{2}{|c|}{$80-110 \mathrm{~kg}$} \\
\hline Lambs per ewe & \multicolumn{2}{|c|}{1.2} \\
\hline
\end{tabular}

The analyses of breed characteristics identified for conservation are shown in Table 2. The decision-making tool used in the present study included the strengths, weaknesses, opportunities and threats associated with a Vlashko-Vitoroga Zackel sheep population tested in our survey (Table 2). The results obtained emphasize the need for development of a strategy for future management and conservation of the breed. 
Table 2. Breed characteristics of the Vlashko-Vitoroga Zackel sheep

\begin{tabular}{|l|l|}
\hline Analysis phases & \multicolumn{1}{|c|}{ Breed characteristics } \\
\hline Strengths & $\begin{array}{l}\text { This sheep is unique for its adaptation to low-cost production } \\
\text { system climatic and other environmental challenges, which } \\
\text { enables survival to some yet-unknown future challenges and } \\
\text { allows maintenance of cultural heritage. }\end{array}$ \\
\hline Weaknesses & $\begin{array}{l}\text { Low production, and lack of interest as well as the lack of } \\
\text { population/genetic knowledge required for conservation activities. }\end{array}$ \\
\hline Opportunities & $\begin{array}{l}\text { Consumer interest in lamb meat of special flavour, milk and } \\
\text { carpet wool from low input system and governmentally supported } \\
\text { ecosystem services. Well adapted to grazing, this, phenotypically } \\
\text { attractive sheep plays in important role in the maintenance of } \\
\text { Deliblatska Pešcara unique ecosystem and helps promotion of } \\
\text { this region. }\end{array}$ \\
\hline Threats & $\begin{array}{l}\text { Small population size, concentrated geographical distribution, the } \\
\text { risk of economically driven decline of breeding, cross/breeding. }\end{array}$ \\
\hline
\end{tabular}

\section{DISCUSSION}

In most recent history, many locally adapted breeds were non-desirable in new intensive breeding programs. The import of selected exotic breeds resulted in a more or less successive introduction into local habitats. Domestic sheep diversity should be conserved for research, training and landscape maintenance purposes. Investigation into immunology, nutrition, reproduction, genetics and adaptive abilities of Vlashko-Vitoroga Zackel sheep should be pursued. Therefore, we performed this study focused on morphological, productive and adaptive traits of this breed. For construction of decision-making tools, in accordance with FAO recommendations (FAO, 2013), we performed an in-depth analysis of the strengths, weaknesses, opportunities and threats associated with a tested Vlashko-Vitoroga Zackel sheep population.

It is well known that breeds of a high economic value are less likely to be at risk. Unfortunately, Vlashko-Vitoroga Zackel sheep is currently considered as a low productive triple-purpose breed. The breed traits of economic importance range from meat and dairy products to woll for traditional clothing and carpets. The prominent morphological characteristic of Vlashko-Vitoroga Zackel sheep are large corkscrewed horns, which make the breed very attractive. All these aspects are currently exploited for tourism purposes, but are only partially recognized by the market. 
Since succession of grassland is ongoing in the area of Deliblatska Peščara due to lack of grazing animals (Cooper et al., 2010), reintroduction of autochthonous sheep on the pastures is a valuable management tool in stimulating diversity at the site (Pykälä, 2005; Hoste, 2011; Marguerat, 2011; Smal, 2011). Conversely, the positive interaction between extensive grazing and ecosystem biodiversity should contribute to the conservation of Vlashko-Vitoroga Zackel sheep.

The results obtained by the analysis of the strengths, weaknesses, opportunities and threats associated with Vlashko-Vitoroga Zackel sheep, clearly show the need for development of future management, conservation and long term rural development and marketing programs strategy. The results of our study are further supported by the obvious cultural importance of sheep breeding in rural South Banat. In addition, the special behavioral, adaptive and morphological characteristics of the Vlashko-Vitoroga Zackel sheep recognized in the present study make the breed suitable for high priority conservation.

ACKNOWLEDGEMENTS:

This study was supported by the Ministry of Education and Science of the Republic of Serbia, Grant No. TR31085.

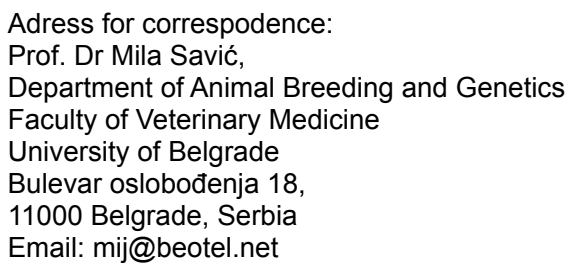

\section{REFERENCE}

1. Baxter BP, Brims MA, Teasdale DC, 1992, The optical fibre diameter analyser (OFDA), new technology for the wool industry, Wool Technol Sheep Breed, 40, 131-4.

2. Ćinkulov M, Popovski Z, Porcu K, Tanaskovska B, Hodžić A, Bytyqi H et al., 2008, Genetic diversity and structure of the West Balkan Pramenka sheep types as revealed by microsatellite and mitochondrial DNA analyses, J Anim Breed Gen, 125, 417-26.

3. Cooper T, Pezold T, Keenleyside C, Đorđević-Milošević S, Hart K, Ivanov S et al., 2010, Developing a National Agri-Environment Programme for Serbia. Gland, Switzerland and Belgrade, Serbia: IUCN Programme Office for South-Eastern Europe, 88 pp.

4. FAO DAD IS, 2012, Domestic Animal Diversity Information System (FAO).

5. Drăgănescu C, Grosu H, 2010, Valachian (zackel) heritage philetic sheep group - A taxonomic problem, Scientific Papers: Romanian Academy, DAGENE - pp 1-7.

6. FAO, 2009, Preparation of national strategies and action plans for animal genetic resources, FAO Animal Production and Health Guidelines No.2, Rome (available at http://www.fao.org/ docrep/012/i0770e/i0770e00.htm).

7. FAO, 2010, Breeding strategies for sustainable management of animal genetic resources, FAO Animal Production and Health Guidelines No.3, Rome (available at http://www.fao.org/ docrep/012/i1103e/i1103e.pdf).

8. FAO, 2012a, Phenotypic characterization of animal genetic resources, Animal Production and Health Guidelines No.11, Rome. 
9. FAO, 2012b, Status and trends of animal genetic resources - 2012, Intergovernmental Technical Working Group on Animal Genetic Resources for Food and Agriculture, Rome, 24-26 October, 2012 (CGRFA/WG-AnGR-7/12/Inf.), Rome.

10. FAO, 2012c, Report of a consultation on the definition of breed categorie, Intergover mental technical working group on animal genetic resources for food and agriculture, Item 5 of the Provisional Agenda, pp 1/7, Rome.

11. FAO, 2013, Draft guidelines on in vivo conservation of animal commission on genetic resources for food and agriculture, Item 4.2 of the Provisional Agenda Fourteenth Regular Session Rome, 15-19 April 2013.

12. Gandini G, Oldenbroek K, 2007, Strategies for moving from conservation to utilization. In K. Oldenbroek, ed, Utilization and conservation of farm animal genetic resources, Wageningen, the Netherlands, Wageningen Academic Publishers 29-54

13. Grdović S, Savić $M$, Bečkei Ž, Dimitrijević $B, 2012$, Biodiversity and traditional sheep grazing in the South Banat region, Acta Vet (Belgrade), 62, 5-6, 709-16.

14. Hoste $H, 2011$, Improving "Low Input" Sheep Production Systems in Europe. First Low Input Breeds Symposium on Ethical Consideration in Livestock Breeding, Wageningen, Netherlands, March 15-16.

15. Lenstra JA, Groeneveld LF, Eding H, Kantanen J, Williams JL, Taberlet $P$ et al., 2012, Molecular tools and analytical approaches for the characterization of farm animal genetic diversity, Anim Gen, 43, 5, 483-502.

16. Marguerat C, 2011, Environmental value of animal genetic resources Book of apstracts of the $62^{\text {th }}$ Annual Meeting of the European Federation of Animal Science No 17, 17. Stavanger 29 August - 3 September.

17. Martin-Collado D, Diaz C, Mäki-Tanila A, Colinet F, Duclos D, Hiemstra SJ, 2012. The use of SWOT analysis to explore and prioritize conservation and development strategies for local cattle breeds, Animal, 20, 1-10.

18. Mitić N, 1984, Ovčarstvo, Zavod za udžbenike I nastavna sredstva, Beograd, 1-504.

19. Nikolić $D$, 1951, Ovčarstvo, Znanje Beograd, 1-133.

20. Pykälä J, 2005, Plant species responses to cattle grazing in mesic semi-natural grassland, Ecosyst Environ, 108, 109-17.

21. Savić M, 2012, Characteristics of Zackel sheep and exotic sheep breeds under sustainable management at the Sjenica-Pester plateu, In: Proccedings of the first Internationale symposium on animal science, 8-10 November, Belgrade, 1131-7.

22. Savić M, Jovanović S, Trailović R, Dimitrijević V, Dimitrijević B, 2011, Autochtonous breeds as livestock potential in sustainable farming in Serbia, In: Proccedings of the $19^{\text {th }}$ Internationale Congress of Mediterranean Federation of health and production of ruminants, 25-28 May, Belgrade, 6-22.

23. Smal RW, 2011, Potential for conservation of local livestock breeds trough delivery of ecosystem service, Book of abstracts of the 62 Annual Meeting of the European Federation of Animal Science, No 17, 73, Stavanger, 29 August-3 September.

24. Stojanović S, 2009, Rare Breeds and Varieties of the Balkan, Atlas,Waltraud Kugler Monitoring Institute for Rare Breeds and Seeds in Europe,128-16.

25. Trailović R, Djedović R, Bogdanović V, Jovanović S, Ćinkulov M, 2006, Pramenka Breed Types of Serbia. In Porcu K and Marković B (eds): Catalogue of West Balkan Pramenka Sheep Breed Types. Faculty of Agricultural Sciences and Food, Skopje, 74-88. 


\title{
UTVRĐIVANJE VREDNOSTI VLAŠKO VITOROGOG SOJA PRAMENKE ZA PROCES KONZERVACIJE
}

\author{
SAVIĆ MILA, TRAILOVIĆ RUŽICA, PETRUJKIĆ B, BEČKEI Ž, DIMITRIJEVIĆ B \\ i DIMITRIJEVIĆ V
}

\begin{abstract}
SADRŽAJ
Pramenka, kao autohtona rasa ovaca, predstavlja važan element za regionalnu agro-biološku raznolikost, tradiciju i kulturnu baštinu Srbije. Saznanja da su lokalno prilagođene rase stekle genetičku otpornost kroz evoluciju, utiču da se principi moderne održive poljoprivredne proizvodnje sve više usmeravaju na potrebu za očuvanje i racionalno korišćenje sojeva pramenke. U radu su opisani faktori rizika koji su doveli do brzog i značajnog smanjenja populacije vlaško vitorogog soja pramenke. Cilj ovog istraživanja je bio da se ispita vrednost soja, kao osnov za razvoj strategije za očuvanje i održivo korišćenje vlaško vitorogog soja pramenke. Utvrđivanje podataka neophodnih za proces konzervacije izvršen je na osnovu karakteristika soja u skladu sa kriterijumima FAO-a. U radu su analizirane pozitivne i negativne karakteristike vlaško vitorogog soja, mogućnosti za korišćenje, kao i ambijentalni izazovi koji utiču na soj. Takođe je razmatran značaj ovog soja za očuvanje kulturne tradicije, zaštite prirodnih celina i dugoročni ruralni razvoj kroz program in situ konzervacije i racionalnog iskorišćavanja.
\end{abstract}

